\title{
KATEKETIKA DALAM SEJARAH PEMIKIRAN PEDAGOSIS KRISTEN
}

\author{
Jefrie Walean \\ STT Bala Keselamatan Palu \\ Jl Merpati 2A Palu \\ Email: jefrywalean@gmail.com
}

\begin{abstract}
Jefrie Walean, Chateketic in history idea Christian Pedagogic. Christian history idea is effort place idea in large of time. Certain to get understanding holistict belived Christian from history idea in the end placed a number of idea which tell as reference doctrine from some church a period history. Christian idea not become property writer of the bible apostles also pater of church but Christian property. Christian idea which concutrently stay in work idea generate way of maner different approach one with otherno wonder that history idea christian write down so munch thinker christian as long as to detected. Clear that,core of Christian ides is human relation with God influence Jesus Christ. Telling about the Christian pedagogic, not realese upon Christian religion didactic.
\end{abstract}

Keywords: Chateketic,History Idea, Pedagogic, Christian

\begin{abstract}
Abstrak: Jefrie Walean, Kateketika Dalam Sejarah Pemikiran Pedagogis Kristen. Sejarah pemikiran Kristen adalah usaha menempatkan peristiwa, ide dalam kurun waktu tertentu untuk mendapatkan pemahaman holistik terhadap apa yang diyakini orang Kristen dari masa kemasa. Sejarah pemikiran Kristen pada akhirnya menempatkan sejumlah ide yang dikemukakan sebagai acuan doktrin dari beberapa gereja masa kini.Sejarah pemikiran Kristen tidak menjadi milik para penulis Alkitab, para rasul serta bapa-bapa gereja, melainkan milik orang Kristen. Pemikiran yang secara bersamaan berada dalam pemikiran dunia menimbulkan cara pandang yang berbeda satu dengan yang lain. Tidak heran bahwa sejarah pemikiran Kristen menuliskan begitu banyak pemikir Kristen sepanjang masa, baik yang terdeteksi maupun yang tidak.Yang jelas bahwa inti pemikiran Kristen adalah hubungan manusia dengan Allah melalui Yesus Kristus. Berbicara tentang semua lingkup pengajaran Kristen, maka tidak lepas dari konsep pendidikan agama Kristen.
\end{abstract}

Kata Kunci: Kateketika, Sejarah Pemikiran, Pedagogis, Kristen.

\section{PENDAHULUAN}

Kompleksitas pedagogis Kristen menggambarkan bahwa pendidikan itu adalah sebuah upaya yang serius karena pendidikan melibatkan aspek kognitif (pengetahuan), afektif (integritas), dan psikomotorik (keterampilan), yang akan membentuk diri seseorang secara keseluruhan menjadi manusia yang berprilaku Kristen. Kateketika merupakan suatu keseluruhan metode pengajaran yang dilakukan oleh gereja untuk menyampaikan, mengajarkan kebenaran Kristen secara terstruktur/terpola agar kekristenan, agama Kristen dapat dikenal serta dipahami oleh orang Kristen itu sendiri. Kateketika susungguhnya bersifat eksklusif karena pemakai adalah orang Kristen.Gereja perlu memperkuat pengajaran, sekalipun ada asumsi bahwa pengajaran bukan hal yang utama. Dualisme ini sering menjadi isu bahwa kebutuhan serta kepentingan dalam gereja menjadi utama ketika kateketika menjadi kebutuhan.Untuk membangun basik dalam pengajaran dalam gereja, maka perlu dimengerti apa itu kateketika.

Kateketika merupakan konsep tertulis yang digunakan sebagai pelajaran sebelum berperang. Para pejuang harus mengetahui medan pertempuran agar dapat menyesuaikan dengan situasi dan kondisi geografis, kualitas musuh. Kateketika dalam perkembangannya dikenal dengan katekisasi yang di dalamnya berisi ajaran tertulis tentang kebenaran firman Tuhan bagi gereja mula-mula. Browning (2007, p. 175)dalam Kamus Alkitab mengatakan bahwa

Katekisasi, kata Yunani "katekhesis", berarti "gema" dan dalam studi PB hal tersebut berupa bagian-bagian dari surat-surat yang dalam se- 
jarah gereja diyakini menggambarkan petunjukpetunjuk lisan bagi mereka yang akan dibaptiskan.

Kata katekhesis berkembangan menjadi katekisasi. Kata katakekisasi dikenal dengan istilah kateketika sebagai bentuk umum dari pengajaran-pengajaran doktrin rasuli yang berisi tentang hal-hal pokok tentang ajaran Yesus serta dogma dari apa yang menjadi dinamika pelayanan rasul, hubungan gereja dengan Negara. Kateketika merupakan perpaduan dari segala bentuk metodologi mengajar tradisional atau konvensional dan modern. Tradisional atau konvensional artinya gaya pengajaran yang menggunakan alat pembelajaran yang tradisional dan mengajar sesuai dengan peran. Namun pengajaran modern harus memenuhi standart kompetensi yang menyeluruh sehingga hasil-hasil pembelajaran dapat dijadikan acuan terhadap bidang ilmu yang terkait. Kata katekisasi berasal dari bahasa Yunani artinya "pelajaran" Istilah ini sudah lama dipakai untuk pelajaran yang diberikan kepada siapa saja yang mau menerima dan mengakui iman Kristen(Porter, 2005, p. 13).

Katekisasi sebagai bahan pengajaran menjadikan para rasul untuk memberitakan Injil melalui pewartaan. Istilah pewartaan Injil disebut Napel (2006, p. 186) sebagai "Kerygma (keryssein membentarakan, mewartakan. Kerygma: pewartaan rasuli." Katekisasi zaman para rasul adalah memberitakan empat hal utama yaitu kelahiran Yesus, kematian Yesus, kebangkitan Yesus dan kenaikan Yesus. Namun dalam perkembangan gereja mula-mula, materi tentang empat pilar pengajaran Yesus mengalami perkembangan dengan memberi ajaran-ajaran rasuli tentang hidup bergereja serta penafsiran-penafsiran surat-surat yang ditulis oleh para penulis Injil dan kitab-kitab rasul Paulus. Manton(1995, p. 87) dalam buku Kamus Istilah Teologi mengatakan bahwa kerygma apa yang diberitakan, dan kata kerusso mewartakan atau memberitakan. Kerygma adalah kata yang digunakan sehubungan dengan pemberitakan yang dilakukan oleh para rasul mengenai Yesus Kristus, kehidupan-Nya, kematiaan-Nya,
kebangkitan-Nya dan kedatangan-Nya kembali. Katekis sebutan guru pengajar yang mengajarkan konsep doa Bapa kami, pengakuan iman rasuli, sepuluh hukum taurat serta pengajaran sinodal gerejawi dari zaman ke zaman. Selanjutnya Stefanus (2009, p. 31) mengatakan bahwa "Gereja pada abad ke 3 semakin sadar akan pentingnya pelayanan pedagodis." Welem (2004, p. 114) dalam buku Kamus Sejarah Gereja, mengatakan bahwa

"Katekese" pengajaran yang diberikan kepada calon baptisan (katakumen). Sebutan ini digunakan untuk buku pengajaran untuk calon baptisan. Buku katekese yang terkenal dari zaman gereja lama adalah karangan Cyrillus dari Yerusalem.

Selanjutnya Welem (2004, p. 114) mengatakan bahwa

Katekismus berasal dari bahasa Yunani Katecheo, artinya mengajar. Pada mulanya kata ini dikenakan kepada pengajaran lisan tentang pokok-pokok kebenaran iman Kristen kepada anak-anak dan orang dewasa sebelum baptisan. Istilah ini juga untuk buku yang berisi pengajaran.Istilah ini tampaknya dipergunakan untuk pertama kalinya pada abab ke-6 namun idenya jauh lebih tua.

Selanjutnya Welem (2004, p. 114) mengatakan bahwa pada masa reformasi pengajaran ini sebagai mainstream karena merupakan upaya gereja mempertahankan status sebagai lembaga yang spiritual yang bersaing dengan pemerintah. Salah satu buku yang terkenal zaman reformasi adalah katekismus Luther yang ditulis pada tahun 1529 sebagai standart gereja Lutheran. Pada tahun 1563, Calvin menulis pengajaran katekismus yang dinamakan Heidelberg.

Rumusan masalah penelitian ini adalah bagaimana landasan berpikir kateketika dalam sejarah pemikiran pedagosis Kristen? Tujuan penelitian ini adalah untuk mengemukakan landasan berpikir kateketika dalam sejarah pemikiran pedagosis Kristen. Manfaat dari penelitian ini adalah untuk memberi kontribusi teoritis historis terkait landasan berpikir kateketika bagi pelaksanaan pendidikan Kristen dan implementasi teologi ke praktik dalam gereja. 


\section{METODE}

Dalam penelitian ini penulis menggunakan analisisdata pustaka. Langkah pertama yang ditempuh dalam menganalisis data yang ditulis oleh para pemikir yang sudah dipilih menjadi sumber referensi. Secara operasional, penelitian ini bertujuan menjelaskan hal yang dijelaskan sebagai landasan bepikir dalam pemikiran kristiani. Secara fungsional penelitian ini bermaksud menambah pengertian dan pemahaman yang komprehensif tentang perkembangan pemikiran pedagogis Kristen. Pengumpulan data dilakukan dengan mengumpulkan beberapa buku, dokumen, karya tulis dan literatur yang relevan. Selanjutnya diolah dengan secara deskriptif eksploratif dengan berusaha menggambarkan keadaan, realita, fakta, data secara realistis. Untuk memberi penajaman terhadap data, penulis menjadikan metode penafsiran teologis sebagai frame penulis sehingga dapat menyimpulkan data sesuai dengan dialektika neo supranatural. Dialektika neo supranatural dilakukan dengan menyerahkan diri kepada Allah dan taat pada penyataan Allah yaitu Alkitab.

Akhir dari penulisan ini maka penulis menggunakan metode induktif yaitu untuk menarik kesimpulan dari yang umum kepada yang khusus dimana sejumlah data premis dibentangkan untuk menarik kesimpulan secara logis.

\section{HASIL DAN PEMBAHASAN}

Kateketika merupakan bentuk suatu pengajaran (pedagogis) yang terencana, terstruktur yang sesuai dengan asumsi teologi Kristen, secara umum dan inklusifisme sinodal tertentu. Artinya bahwa kateketika masuk dalam ranah didaktik metodik (metodologi pembelajaran Kristen) sehingga pemakaian secara operasional dikategorikan sebagai makna pedagogis Kristen. Pratiwi (2017, p. 37) menjelaskan bahwa istilah didaktik berasal dari bahasa Yunani "didaskein" yang berarti pengajaran maupun pandai mengajar, dengan demikian didaktik dapat diartikan sebagai sebagian dari pedagogik atau ilmu mendidik. Dalam konteks Kristen, pengajaran katekisasi Kristen, berusaha agar sesorang dapat mengi- kuti apa yang menjadi dasar pengajaran Kristen. Sedangkan belajar secara umum adalah suatu proses mencari dan menemukan serta memberi arti dari apa yang diajarkan. Ada berbagai pengertian dari belajar sebagai salah satunya adalah belajar merupakan suatu proses yang dilakukan oleh individu agar memperoleh perubahan pengetahuan kemudian perubahan tingkah laku sebagai pengalaman individu itu sendiri (Aritonang, 2008, p. 13). Selanjutnya Stefanus $(2009$, p. 30) mengatakan bahwa katekese merupakan jawaban gereja purba untuk menanggulangi masalah banyaknya orang dewasa ingin mengabdikan diri kepada Kristus. Pengajaran Kristen akan menjadi kebutuhan ketika pengajaran Kristen wajib diberikan saat itu antara lain, ketika ada waktu yang cukup untuk masuk dalam acara baptisan. Artinya sebelum dibaptis seseorang harus memiliki dasar Alkitabiah. Sementara jika terjadi peristiwa dibaptis dulu baru diajar, maka hal ini memerlukan kejelian seorang pemimpin gereja untuk mengukur tingkat kerohanian serta komitmen yang bersangkutan untuk menjadi seorang Kristen. Namun dalam kasus tertentu langkah katekisasi sebelum dan sesudah dibaptis merupakan hal yang urgen untuk dilakukan. Kemudian bila ada yang melakukan baptisan ulang maka dalam kasus tertentu perlu dilihat secara komprehensif agar tidak salah. Sejak dimulainya usaha pedagogis para rasul di Perjanjian Baru, tentunya dilihat secara komprehensif bahwa segala bentuk pengajaran dimulai sejak Perjanjian Lama. Pengajaran tentang larangan Allah tentang buah baik dan jahat menjadi acuan bahwa pengajaran telah dimulai sejak penciptaan sehingga dapat dikatakan bahwa pengajaran menjadi salah satu bidang yang seumur dengan usia bumi serta peradabaan manusia menurut konteks Alkitab. Allah menyuruh para nabi antara lain Musa untuk menyampaikan sepuluh hukum Taurat bagi bangsa Israel. Bagi umat Israel, hukum Taurat adalah materi rohani yang harus dipahami dan dijalankan oleh umat Israel dalam konteks "providensia" (pemeliharaan Allah atas umat Israel).

Dengan demikian umat Israel menjadikan

Taurat sebagai hukum rohani. Sepuluh hukum 
Taurat mengandung dua unsur relasi yaitu hukum 14 berbicara tentang hubungan manusia dengan Allah (vertical) sedangkan hukum ke 5-10 berbicara tentang hubungan manusia dengan manusia (horizontal). Boehlke (2009, p. 1) dalam bukunya mengatakan bahwa ruang lingkup pembahasan tentang sejarah pendidikan agama Kristen sudah mencakup dasarnya dalam kebudayaan Yunani, Romawi dan Yahudi, kemudian perkembangannya dimulai sejak kelahiran Yesus dari Nasaret sampai pada tahun 1556 yakni wafatnya Ignatius Loloya pendiri Kompi Yesus dan pelopor sistem persekolahan yang turut meraih kembali sebagian daerah Eropa Barat yang sudah memeluk agama Protestan. Sementara pemikiran Kristen dimulai sejak Kristus lahir atau tepatnya komunitas jemaat Kristen pertama. Pendapatpendapat yang berhubungan dengan Kristus serta pemikiran-pemikiran tentang Yesus adalah bagian dari sebuah pemikiran Kristen. Pemikiran Kristen artinya berbicara hal-hal yang bersifat Kristen atau berbicara konsep kekristenan. Berbicara tentang pemikiran Kristen, maka objek yang dibicarakan adalah Alkitab dan subjeknya adalah manusia. Dalam konteks Kristen, maka Alkitab merupakan sumber utama dari pemikiran Kristen sepanjang masa. Dan manusia adalah subjek penerima dari hasil pemikiran Kristen dan manusia jugalah yang berusaha membangun konsep Kristen itu. Minimal ada dua sumber pemikiran Kristen antara lain Alkitab secara tertulis pandangan atau tafsiran. Alkitab melalui penulisnya menuliskan kisah-kisah historis yang ditafsirkan melalui berbagai metodologi yang selanjutnya menjadi ukuran dogma dan doktrin Kristen. Sepanjang sejarah Kristen, sudah banyak pandangan yang dikemukakan oleh beberapa orang tentang Alkitab dan terutama mengenai Yesus. Sumber-sumber tersebut telah menjadi kerangka berpikir Kristen dari masa ke masa. Dengan demikian perbedaan tafsir karena perbedaan titik berangkat secara hermenutik menghasilkan beragam ide teologi yang sering menjadi ajang adu argumentasi. Penulis tidak bermaksud memberikan pandangan yang akhirnya memupuk perbedaan, namun dari sisi pandangan pentakosta, beragam ide teologi ternyata belum mampu menjawab secara komprehensif datadata Alkitab sehingga dengan demikian "jangan" mengatakan idenya lebih superior. Tulisan ini mencoba menyerap pemikiran-pemikiran dari beberapa orang terdahulu yang banyak diispirasikan, dijadikan patron bagi warna teologi.

\section{Perspektif Alkitab Perjanjian Lama}

Perjanjian Lama adalah salah satu sumber dogmatika Kristen dari waktu ke waktu. Bersama perjanjian baru memberi ide teologi yang menjadi doktrin orang Kristen sampai saat ini. David Baker (1994, p.13) dalam bukunya mari mengenal Perjanjian Lama bahwa

Perjanjian Lama sering dikutip oleh Perjanjian Baru. Ada kurang lebih 2650 dari Perjanjian Lama dalam Perjanjian Baru yaitu kurang lebih 350 kutipan langsung, dan dari 2300 kutipan tidak langsung serta persamaan bahasa. Dengan kata lain terdapat rata-rata kutipan Perjanjian Lama dalam setiap tiga ayat Perjanjian Baru.

Namun diakui bahwa multi opini yang dimiliki oleh para teolog yang mengapresiasi kepada sumber yang sama serta Allah yang sama, sekalipun implementtasinya yang berbeda. Perjanjian Lama memberikan suatu pandangan sejarah penyelamatan Allah yang di kenal dengan perjanjian Allah dengan Israel yang disebut von Rad sebagai heigelsciete atau sejarah keselamatan. Timbulnya pertanyaan mengapa Israel menjadi miniatur pemikiran Kristen? Kemudian apakah Israel itu Kristen? Sesungguhnya Israel adalah sebuah Negara yang mayoritas berkeyakinan Yudaisme sebagai karena memeluk sistim peribadatan Perjanjian Lama. Dengan kata lain Israel tidak identik dengan agama Kristen. Disamping Yudaisme, Kristen ortodoks juga ada disana bersama dengan keyakinan agama yang lain seperti Islam dan Katolik serta denominasi gereja. Penyebutan agama Kristen adalah suatu sebutan untuk komunitas pengikut jalan Tuhan dalam Kisah Para Rasul ketika kumpulan orang yang telah percaya mengikut ajaran para rasul yang pada akhirnya disebut Kristen yang berasal dari sebutan bahasa Inggris, Christian. Blommendaal, 
(1996 p.10) menjeaskan bahwa bahwa ketika perjanjian itu diikat oleh Abraham yang adalah nenek moyang orang Yahudiada dua perihal Perjanjian Lama yaitu Perjanjian Lama sebagai landasan yuridis dan sebagai penyataan kenabian. Penyataan kenabian dan kitab historis tersebut memuat teks yuridis dan ajaran kesusilaan-praktis, kemudian ajaran kebijaksanaan atau hikmat dan nyanyian serta lagulagu dalam ibadah.

\section{Perspektif Perjanjian Baru}

Jika titik berangkat dimulai dari Perjanjian Baru, maka penulis memulainya dengan Yesus, dan tidak berbicara tentang proses lahir, melainkan dimulai dengan opini-opini selama di bumi ini. Para ahli berpendapat bahwa Yesus berada dibumi kurang lebih 33-34 tahun.Dan dikatakan bahwa kurang lebih tiga tahun Yesus memberikan pelayanan secara holistik dan kontekstualdi wilayah Palestina.

\section{Yesus Sebagai Guru}

Yesus adalah figur guru yang disebut dalam kitab injil sebagai "guru" (didaskolos). Yesus dicatat dalam ketiga Injil Sinoptik dan Injil Yohanes yang senang berinteraksi secara pedagogis kepada orang banyak. Yesus dikatakan sebagai seorang pengajar. Injil mencatat bahwa Yesus mengajarkan tentang masalah horizontal yaitu hubungan manusia dengan manusia, dan vertikal yaitu hubungan manusia dengan Allah. Para Rasul sebagai saksi dalam memberitakan Yesus yang sudah naik ke sorga. Dalam Injil disebutkan bahwa Yesus mengangkat 12 rasul yang dominan menemani Yesus dalam pekabarn Injil.

Alkitab mencatat bahwa ketika Yesus kembali ke sorga seperti yang saksikan Alkitab, maka para rasul adalah orang yang memberi kesaksian terhadap perkataanYesus, dan para rasul yang meneruskan pekabaran Yesus. Namun berbeda dengan Yesus yang memberitakan kerajaan Allah, para rasul memberitakan Injil yang berisi tentang riwayat Yesus mulai dari nubuat dalam Perjanjian Lama sampai naik ke sorga. Itulah berita yang dikenal dengan pemberitaan gereja mula-mula atau kerygma. Kata kerygma adalah kata Yunani dalam Perjanjian Baru yang erat hubungannya dengan pemberitaan verbal perihal Yesus Kristus. Manton (1995, p. 87) menulis kerygma artinya apa yang diberitakan sedangkan akar kata kerusso artinya mewartakan atau memberitakan. Dalam konsep gereja awal, kerygma dihubungkan dengan pemberitaan yang dilakukan oleh para rasul mengenai Yesus Kristus, kehidupan, kematian, kebangkitan dan kedatangan-Nya kembali.

\section{Pasca Para Rasul}

Intinya bahwa komunitas Kristen yang dicatat dalam Kisah Rasul 4 merupakan akibat langsung dari peristiwa pada hari pentakosta (pasal 2). Beberapa penulis teologi modern berpendapat bahwa bilangan para rasul Yesus ada 12 namun paska rasul rasul itu, muncul tokoh Paulus yang sebelumnya Saulus. Mungkin saja kerygma Yesus masih menjadi pemberitaan "hangat" dikalangan Kristen Yahudi dan Kristen diaspora. Stefanus (2009, p. 23) dalam bukunya mengatakan bahwa Sejarah PAK gereja purba terjadi antara abad ke 2 hingga abad ke 5 . Pada Awal abad ke 2 para pemeluk agama Kristen sedikit sekali jumlahnya sekalipun sudah ada kelompok-kelompok Kristen yang mendiami banyak kota disekitar Laut Tengah. Para pemikir berpendapat bahwa kitab-kitab Perjanjian Baru sudah selesai ditulis pada akhir abad pertama.

\section{Pemimpin Gereja Purba}

Sejak komunitas pengikut Kristus disebut Kristen, maka ada tantangan gereja yang terbesar adalah penguasa Romawi. Berbeda dengan Yesus justru tantangan terbesar dari para iman dan ahli taurat. Gereja purba mendapatkan tantangan ideologi antara lain helenisme Yunani, Yudaisme, Deisme Romawi. Sejak abad pertama Roma adalah penguasa dikawasan Asia kecil termasuk di kota Yerusalem tempat Yesus dan murid-murid-Nya mengadakan "dakwah" kerajaan Allah. Bahkan Injil mencatat bahwa ketika Yesus diserahkan oleh para iman dan ahli taurat untuk dihukum, pemerintahan Romawi 
yang bertugas mengeksekusi Yesus sekalipun Yesus tidak ada sangkut paut dengan hukum Romawi. Pemerintah Roma menganggap bahwa kaisar adalah "tuhan" yang harus disembah. Banyak pengkikut Yesus yang harus dihukum karena tidak mau memberikan penghormatan kepada kaisar. Selanjutnya Stefanus (2009, p. 24) menulis bahwa "Tertulianus seorang teolog dari Afrika utara yang hidup pada abad ke 3, menantang gereja agar tidak memanfaatkan bahan yang dikarang oleh sarjana bukan Kristen." Ini merupakan pukulan bagi pemerintahan Romawi sehingga mendorong mereka untuk menganiaya para pengikut jalan Tuhan atau pengikut Kristus. Selanjutnya Stefanus (2009, p. 24) menulis bahwa Hieronimus dari kota Anthiokhia yang terletak di Siria Modern yang hidup sekitar abad ke 4 memiliki sikap yang lain jika dibandingkan dengan karangan kafir, Alkitab jauh lebih rendah mutunya dan kurang cukup kuat untuk mendorong pemikiran yang mendalam dengan demikian Hieronimius justru berpihak pada pemerintah Romawi dan kebudayaan Yunani. Selanjutnya Stefanus (2009, p. 24) mengatakan bahwa "Basil (330-379) dari kaisarea, suatu kota di Kappadokia (turki modern) berusaha membedakan antara karangan yang boleh dimanfaatkan oleh gereja dan karangan yang perlu ditolak.”

Gereja purba dengan kepercayaan injilnya harus berhadapan dengan aliran-aliran keagamaan Yudaisme, kebudayaan Romawi, serta intelektual Yunani. Aliran keagamaan antara lain gnostik, mitrasisme dan platonisme. Gnostik mempertanyakan hubungan keselamatan Yesus dengan keselamatan manusia.Gnostik memandang bahwa ada perbedaan esensi Allah dengan manusia sehingga tidak bisa dikatakan bahwa Allah menjelma dari manusia. Ajaran mitraisme adalah agama yang menghubungkan antara jasmani dan rohani, antara dewa matahari dengan tumbuhan atau hewan. Dewa Mitraisme yang dipercaya sebagai perpaduan dewa dan matahari ini dikenal dengan "dues Sol Invictus" (Stefanus, 2009, p. 26). Orang Romawi menganggap bahwa kaisar sebagai dewa matahari yang kuat. Ajaran neoplatonisme yang bertumbuh di Alexsandria
Mesir sekitar abad ke 3 yang mengajarkan bahwa jiwa harus dilepaskan dari belenggu jasmani untuk berjumpa dengan Allah. Gereja purba juga mengalami tuduhan ketidaksetiaan kepada pemerintah Roma dengan menyebar isu menentang kaisar sehingga banyak orang Kristen yang dikejar untuk di bunuh. Adalah seorang Jutstin Martyrseorang Kristen abad ke 2 memohon agar pemerintah Romawi menarik asumsi bahwa orang Kristen tidak setia kepada pemerintah Roma (Stefanus, 2009, p. 28). Stefanus (2009, p. 29) menulis

Origenes seorang teolog dari abad ke 3 melalui karyanya yang terkenal Contra Celcius berusaha menjawab tuduhan tersebut. Ia menyatakan bahwa banyak pemimpin gereja yang dapat digolongkan dalam kelompok cedekiawan yang tidak membatasi penyelidikannya pada sumber iman saja, melainkan mencakup juga tulisantulisan yang bukan dari pena orang Kristen.

Kemudian sekitar abad pertama sampai kedua, seorang pengajar gereja bernama Clements (150215M) dan Clements berusaha menjembatani pemikiran Kristen dengan kebudayan Yunani (Stefanus, 2009, p. 34).

Tiga karya Clements yang dianggap sebagai karya pemikir Kristen yaitu "protrepikos" yang berbicara tentang nasihat-nasihat, pedagogis yang berbicara tentang seorang pendidik dan Stomateis yang berbicara tentang pengajaran umum terhadap kehidupan. Namun besar dalam sejarah pemikiran Kristen dan ilmu pengetahuan. Clement merupakan salah satu pemikir Kristen yang sangat kuat mempengaruhi dalam hal katekisasi Kristen purba. Dengan kata lain bahwa Clement mencoba menggunakan filsafat Yunani dengan nilai Kristen sehingga menghasilkan pengajar dalam bidang pedagogis atau bidang pengajaran. Sekitar tahun 185-224 M, juga seorang pemikir Kristen gereja purba yang bernama "Origenes" (Stefanus, 2009, p. 36). Sebagai murid Clement, ia menjadi seorang pengajar katekisasi. Origenes menghargai filsafat sebagai alat untuk menolong dalam pemikiran ilahi. Pengalaman dapat diperoleh dari proses berpikir. Origens juga mengajarkan penafsiran alegoris dalam mengajarkan 
katekisasi. Origenes seorang didaskalos yang menolong para murid untuk memahami pengetahuan bersama dengan pengetahuan filsafat. Sekitar tahun 345-420 M seorang yang bernama Hieronimus adalah seorang yang menterjemahkan Alkitab dari bahasa Ibrani dan Yunani dalam bahasa Latin (Vulgata) Hieronimus juga seorang pendidik yang mengajarkan Alkitab sekaligus pemahaman yang sederhana untuk dipahami (Stefanus, 2009, p. 38).

Sekitar tahun 347 seorang bernama Yohanes Chrysostomus sebagai seorang pengkotbah dengan gelar maha guru (Stefanus, 2009, p. 41). Yohanes Chrysostomus menjadi pengkotbah yang sangat disukai banyak kalangan. Yohanes Chrysostomus mengajarkan bahwa orang tua harus mendidik anaknya dengan baik serta mengajarkan segala kehidupan yang sesuai dengan ajaran gereja. Sekitar tahun 354-430 M seorang bernama Augustinus lahir di Afrika Utara dan menjadi seorang teolog gereja Katolik dan Protestan (Stefanus, 2009, p. 43). Pemikiran Augustinus tentang pendidikan Kristen seharusnya Kristus sebagai acuan. Dengan demikian, dalam konteks pedagogis Kristen, seorang guru harus memiliki kompetensi kristiani yang kokoh serta fundamen sebelum memberikan pengajaran Kristen. Guru Kristen Augustinus berpendapat bahwa eksistensi Allah tidak berhenti pada kanon Alkitab saja, namun masih terlibat secara kontinuitas sejarah masa lalu (past) masa kini (present) dan masa yang akan datang (future).

\section{Pedagogis Dalam Pemikiran Kontemporer}

Dalam perkembangan berteologi, muncul beragam varian teologi yang dicatat dalam beragam buku teologi ditingkat sekolah teologi. Perkembangan teologi khsususnya pada abad ke 19 di kenal dengan istilah "teologia kontemporer" yang diperkenalkan Karl Barth(1886-1968). Sebagai seorang teo$\log$ neoortodoks menyampaikan ide teologi yang melawan ide lama. Karl Barthpernah belajar teologi di bawah pemahaman teolog liberal antara lain Harnack. Selain itu, pemikiran filsafat serta penemuan Copernicus tentang bumi serta pencerahan ide filsafat Imannuel Kant juga telah memberikan warna teologi sampai saat ini.

\section{Era Reformasi}

Salah satu tokoh sentral dari reformasi gereja adalah Marthin Luther. Baker (2009, p. 38) mengungkapkan bahwa "Reformasi adalah suatu gerakan yang muncul dalam sejarah gereja Kristen di Eropa Utara. Masalah utama pada masa itu adalah Alkitab." Para reformator seperti Martin Luther dan Calvin berbicara tentang Alkitab sebagai otoritas tertinggi dan secara kritis menolak filsafat yang merasuk ajaran Kristen waktu itu. Masa reformasi dimulai sekitar tahun 1483 sampai pertengahan tahun 1800. Masa itu telah memunculkan ide-ide baru dalam berteologi. Marthen Luther yang hidup pada tahun 1483-1546 mengakui kesatuan Alkitab maupun keanekaragaman dalam Alkitab. Menurut Luther, bahwa Alkitab adalah Kristus dan keanekaragamannya adalah hukum-hukum dan Injil. Reformasi merupakan suatu reaksi ketidakpuasan atas kenyataan sekularisme yang dipengaruhi oleh filsafat. Gejolak teologi pada masa itu dilakukan oleh Luther ketika ia memakukan sembilan puluh lima tesis dipintu gereja di Wittemberg pada tanggal 31 oktober 1517. Luther memprotes secara tegas tentang doktrin soteriologi yang diajarkan gereja Roma Katolik, yaitu penghapusan dosa yang dapat dilakukan oleh seorang rohaniawan. Akibatnya Luther dikucilkan dan ditentang. Reformasi telah merangsang berkembangnya ajaran-ajaran baru yang bertolak dari ketidakpuasan secara pribadi, sehingga membangkitkan perhatian yang sangat besar untuk mengkaji Alkitab secara sungguh-sungguh. Akibat reformasi, munculah dalam kubu pro dan kontra tentang pelayanan dengan kuasa. Situasi pada abad 17 sampai abad 19 merupakan masa bertumbuhnya "multi teologia". Pemikiran teologi alkitabiah menyatakan bahwa semua orang berstatus berdosa dan hanya oleh anugerah Tuhan manusia mendapatkan keselamatan. Bagi Marthin Luther, tujuan dari pendidikan Kristen adalah menyadarkan manusia tentang dosa. Alkitab harus dipahami sebagai standart bagi semua penga- 
jaran Kristen. Marthin Luther mendorong orang Kristen bukan saja mempelajari Alkitab, namun mempelajari berbagai pengetahuan antara lain, sastra, sejarah, musik. Marthin Luther menolak asumsi Aristoteles yang mengatakan bahwa usaha berbuat baik seorang akan menjadi baik. Bagi Luther akal budi melalui anugerah Allah adalah dasar untuk melakukan kebaikan.Konsep kembali kepada Alkitab, hanya karena anugrah dan hanya karena iman adalah dalil reformasi yang sangat kuat memengaruhi hubungan orang Kristen dengan orang Kristen yang lainnya khususnya Katolik yang akhirnya memusuhi Marthin Luther. Dalam bidang katekisasi, Luther menyusun katekismus besar yang isinya tentang halhal berkenaan dengan Alkitab dan iman kepada Yesus Kristus. Luther adalah penggagas pendidikan anak yang harus dilakukan gereja bersama gereja.

Pemikir Kristen zaman reformasi lainnya adalah Yohanes Calvin. Karyanya yang terkenal yaitu "Institutio Christianae Religionis". Bagi Calvin pemikiran Kristen sebagai doktrin yang kuat sebagai pemupukan akal orang percaya di bawah bimbingan Roh Kudus. Calvin mempercayai sebuah doktrin bahwa Allah telah memilih sebagai orang yang diselamatkan. Ada beberapa tokoh yang memberi opini tentang makna ini misalnya Tomas Aquinas. Namun mereka sadar bahwa orang-orang Kristen sudah berbicara secara mendetail tentang Allah dan ia mencoba mengungkapkan apa maksud bahasa transsenden Allah ditekankan. Dapat saja menggunakan bahasa antropomorfis tentang Allah tetapi perlu disadari bahwa hal ini tidak dapat mengatakan bagaimana sebenarnya Allah itu di dalam diri-Nya sendiri. Allah berada di luar waktu, dengan demikian semua peristiwa yang pernah terjadi atau akan terjadi serentak Allah hadir dihadapan-Nya.

Seorang pemikir Kristen dizaman reformasi yang lain adalah Yohanes Amos Comenius, lahir di Morawi Tenggara Honggaria. Comenius disebut sebagai bapa pendidikan modern khususnya dibidang pendidikan agama Kristen (Boehlke, 2009, p. 1). Selanjutnya Boehlke (2009, p. 25) mengatakan bahwa "Comenius berpendapat bahwa pendidikan yang ia maksudkan selayaknya dinamakan pendidikan agama Kristen, karena nilai-nilainya berporos pada iman Kristen." Kekristenan tradisonal mengklaim bahwa Kristus datang untuk membawa kehidupan kekal bagi mereka yang mengikuti-Nya. Kehidupan kekal sebagaimana kehidupan tanpa akhir sesudah kematian bagi individu didalam kerajaan sorga. Di sana mereka tinggal dihadirat Allah. Kehidupan kekal adalah setiap individu akan melihat Allah. Adanya kejahatan adalah ancaman terbesar bagi kredibilitas ide tentang Allah yang dilihat sebagai individu yang kekal atau sebagai substansi yang tidak dapat dibatasi waktu. Allah yang secara sempurna yang mempunyai kekuatan yang tidak terkalahkan akan mencegah kejahatan amun kejahatan itu ada. Kejahatan alamiah bagaimanpun juga lebih sulit dijelaskan kecuali atas dasar bahwa Allah harus mengijinkan terjadinya kejahatan ini supaya mengembangkan kebijakan manusia atau supaya menyatakan kekuasaan-Nya dengan hasil yang paling baik.

Boehlke (2009, p. 101) mengungkapkan bahwa tokoh Kristen yang ikut mempengaruhi pemikiran Kristen lainnya adalah Jean Jacques Rousseau. Darmawan (2016) mengungkapkan bahwa Rousseau adalah seorang yang besar di Perancis dan memberikan pemikiran Kristen antara lain memberikan perhatian dalam pendidikan kepada anak dalam sebuah buku yang berjudul Emile. Buku Emile berisikan tentang penentangan terhadap status quo dalam Negara. Pada intinya para pemikir Kristen memandang bahwa dia adalah salah satu tokoh pembaharu dalam dunia pendidikan Kristen. Pemikiran pendidikan Rousseau tidak lepas dari situasi masyarakat yang terjadi pada itu dan pemikirannya tentang kontrak sosial (Darmawan, 2016).

Pemikir Kristen lainnya adalah Robert Raikes sebagai pendiri ide sekolah minggu. Robert Raikes sebagai pendiri sekolah minggu Raikes melihat bahwa pendidikan Kristen menjadi tanggungjawab gereja kepada anak-anak (Boehlke, 2009, p. 379). Darmawan (2015) kemudian menjelaskan bahwa pemikiran Raikes kemudian menginspirasikan pelayanan "sekolah minggu" pada masa modern, 
substansinya adalah memperkenalkan dogma-dogma Kristen reformasi kepada anak-anak. Dogma gereja bukan hanya tertulis namun dapat dialami dan bukan menjadi pengalaman "keagamaan" Dalam hal itu pengalaman keagamaan yang mencakup: a) hubungan dengan ajaran-ajaran gereja atau ajaran-ajaran Alkitab, kriteria moral, keyakinan. Agustinus menjadi salah satu tokoh pengangum Plato menyadari bahwa pengalaman keagamaan harus masuk level berikutnya yatu pertobatan. Linda Smith dan William Rapper (2004, p. 25) Agustinus bertobat dan berubah. Ia percaya bahwa kebenaran yang tidak ditemukan dalam akal budi. Ia menyadari bahwa manusia tidak diselamatkanoleh kekuatannya sendiri. Bagi Agustinus Allah adalah kebaikan tertinggi."

\section{Filsafat Relativisme (Nalar dan Logika)}

Semenjak kebangkitan abad renaissance dan humanisme sekitar abad ke 17 di Eropa kajian Alkitab semakin diperuncing dengan filsafat Yunani dengan aliran-aliran perfeksionisme. Tidak dapat disangkal bahwa Alkitab dianggap buku yang usang dan tidak bermutu akademik sehingga perlu dikaji. Di zaman kekristenan, filsafat menjadi unsur pemikiran mengenai penulisan Alkitab. Pada masa itu banyak dari filsafat Yunani mengembangkan agama yang diajarkan oleh Plato, dan Aristoteles yaitu monotheisme transsenden. Monotheisme filsafat inilah yang menjadi titik pertemuan dan menjadi dasar pemikiran Kristen. Namun terjadi kesenjangan antara konsep Yunani tentang Allah dengan pemikiran penulis Alkitab. Menurut konsep Yunani, Allah tak berubah, maka Ia tidak mungkin berubah dan berhubungan dengan dunia. Karena dunia adalah fana dan Allah adalah hakikat "Ada" yang tak terbatas. Jadi pola pemikiran Yunani itu belum mendekati pada gambaran tentang Kristus. Filsafat bahkan merubah konsep pemikiran penulis Alkitab, sehingga lambat laun pemikiran Yunani berkembang menjadi pemikiran Kristen. Namun selama proses perubahan itu, terjadi pergeseran yaitu pemikiran Yunani yang tidak sesuai disingkirkan. Tony Lane (2005, p. 6) memberi penjelasan tentang hubungan penulisan
Alkitab dengan filsafat bahwa agama Kristen pada gilirannya dilihat melalui kaca mata Yunani. Filsafat telah membuka peluang untuk menafsirkan Alkitab itu dengan perspektif Yunani. Filsafat yang meliputi pikiran, tingkah laku, nilai, tujuan hidup merupakan unsur yang ada pada manusia. Filsafat membuka peluang manusia untuk mencari kebenaran melalui pengalaman budi dan berhak menentukan apa yang akan dilakukan, tanpa dipengaruhi oleh orang lain. Karena masing-masing dengan kemampuan pengetahuan yang ia dapat, ia mampu untuk merealisasikan dalam hidupnya. Dengan kata lain bahwa dalam filsafat kebebasan adalah kehendak manusia secara natural.

\section{Modernisasi Dan Globalisasi}

Modernisasi dan globalisasi merupakan aspek yang tidak dapat terlepas satu dengan yang lain. Selanjutnya modernisme merupakan bentuk peralihan dari yang tradisional menjadi lebih canggih. Dengan kata lain jika modernisme ditempatkan pada konteks waktu, maka apa yang dihasilkan dalam waktu ini yaitu penemuan produk teknologi yang muktahir yang menganulir cara konvensional atau tradisonal apalagi pelayanan dengan kuasa yang hanya mengandalkan doa dan puasa, bertobat yang menjadi ciri khas Pentakostalisme. Penemuanpenemuan dibidang biologi, kimia, matematika sudah mendominasi riset ilmiah di benua Eropa dan Amerika sejak abad pertengahan. Akibat perkembangan ilmu dan teknologi dalam bidang biologi, maka seorang bernama Charles Darwin mengemukakan teori asal usul manusia. Ini sangat "memukul" para teolog Kristen yang mulai mencari kebenaran yang mutlak. Modernisme telah menciptakan suasana baru sehingga segala sesuatu ikut mengalami perubahan. Webster (1986, p. 33) menyatakan bahwa manusia modern selalu ingin maju. Manusia modern selalu bersifat kekinian dan selalu menuju kepada hasil masa kini. Manusia modern berpikir pada masa kini seperti cara berpakaian, berbahasa, berkendaraan, belajar, berpolitik, berbisnis. Akhirnya modernisme membentuk karakter manusia menjadi 
materialisme yang akhirnya mementingkan harta benda dari pada kebutuhan rohani dan pelayanan dengan kuasa. Jadi, dunia di mana manusia hidup telah memasuki masa atau zaman yang bergerak dinamis yang secara drastis merubah konsep-konsep serta cara-cara tradisionil ke dalam bentuk tatanan baru. Komunitas dan Gereja masa kini menghadapi tantangan pelayanan yang harus dihadapi dengan kuasa yang supranatural.

\section{KESIMPULAN}

Pedagogis Kristen telah mengalami dinamika perubahan yang sangat signifikan searah dengan perkembangan zaman atau peradaban manusia. Alkitab berada dalam polarisasi yang membuat pemikir Kristen dari zaman ke zaman untuk konsekuen dan konsisten untuk menjadikan sumber pemikiran tetap kokoh dan relevan dari masa kemasa. Pedagogis Kristen adalah bagian yang tidak terpisahkan dari

\section{DAFTAR RUJUKAN}

Aritonang, K. T. 2008. "Minat dan Motivasi dalam Meningkatkan Hasil Belajar Siswa."Jurnal Pendidikan Penabur, 7(10): 11-21.

Baker, D. 1994.Mari Mengenal Perjanjian Lama Jakarta: BPK Gunung Mulia

Baker, D. 2009. Satu Alkitab Dua Perjanjian. Jakarta: BPK Gunung Mulia.

Blommendaal, J. 1996.Pengantar Perjanjian Lama. Jakarta: BPK Gunung Mulia

Boehlke, R. 2009. Sejarah Perkembangan Pikiran dan Praktek Pendidikan Agama Kristen. Jakarta: BPK Gunung Mulia.

Browning. 2007. Kamus Alkitab. Jakarta: BPK Gunung Mulia.

Darmawan, I.P.A 2015. Dasar-Dasar Mengajar Sekolah Minggu. Ungaran: Sekolah Tinggi Teologi Simpson.

Darmawan, I. P. 2016. "Pendidikan 'Back toNature': Pemikiran Jean Jacques Rousseau Tentang Pendidikan."Satya Widya, 32 (1): 11-18. kateketika Kristen dari masa ke masa. Ukuran yang menjadi titik pijak serta tolak ukur kateketika Kristen selalu berpangkalpada ajaran Alkitab adalah firman Allah. Ajaran Perjanjian Lama dan Perjanjian Baru berada pada kohesi dan koheren yang masih relevan seiring dengan luasnya pemikiran pada era milenial ini. Opini pemikiran barat dan Helenis tidak dapat disangkal menjadi ide besar teologi dan pedagogi Kristen di Indonesia. Namun sampai hari ini upaya mengkontekstualisasi masih menjadi salah satu metode yang memiliki pengaruh pendekatan. Lautan ide pedagogis dipersilahkan mencari bentukbentuk baru "asalkan" substansi dari pengajaran Kristen bisa didengar oleh semua orang. Dengan demikian uraian tertulis dalam agama Kristen akan menjadi tulisan yang hidup dalam perilaku, tindakan orang percaya. Akhirnya pengajaran agama Kristen menjadi kekuatan yang utuh ibarat dua sisi mata uang.

Lane, T. 2005. Runtut Pijar. Jakarta: BPK Gunung Mulia.

Smith, L.\& Rapper, W. 2004.Ide Filsafat Dulu dan Sekarang. Yogyakarta: Kanisius

Manton. M.E. 1995. Kamus Istilah Teologi. Malang: Gandum Mas.

Napel, H. T. 2006. Kamus Teologi Inggris-Indonesia. Jakarta: BPK Gunung Mulia.

Porter. 2005. Katekesisasi Masa Kini. Jakarta: Yayasan Komunikasi Bina Kasih/OMF.

Pratiwi, R. 2017. "The Importance of Team Management for Teachers."Jurnal Ilmiah Pendidikan Scholastic, 1 (3): 34-44.

Stefanus, D. 2009. Sejarah PAK. Bandung: Bina Media.

Webster, D. 1986. Kehidupan Kristen Dalam Kebudayaan Dunia. Malang: Gandum Mas.

Welem, F. 2004. Kamus Sejarah Gereja. Jakarta: BPK Gunung Mulia. 